\title{
TEN-YEARS COMPARATIVE STUDY AFTER SURGICAL TREATMENT OF PERFORATED PEPTIC ULCER ACCORDING TO ULCER RELAPSE BETWEEN H. PYLORI POSITIVE, AFTER ERADICATION, AND NEGATIVE PATIENTS
}

\author{
Estudo comparativo quanto à recidiva ulcerosa do tratamento cirúrgico de úlcera \\ péptica perfurada entre pacientes $\mathrm{H}$. Pylori positivos, após erradicação, e negativos
}

\author{
Rosa Pachaly DALCIN, Cristiano Antoniazzi ABAID, Paola M. ALMEIDA, Samia B. ADAIME, \\ Thiza Massaia LONDERO, Lucas V. GAI
}

\begin{abstract}
ABCDDV/632
Souza FO, Dalcin SR, Dalcin RP, Abaid CA, Almeida PM, Adaime SB, Londero TM, Gai LV. Ten-years comparative study after surgical treatment of perforated peptic ulcer according to ulcer relapse between H. Pylori positive, after eradication, and negative patients. ABCD Arq Bras Cir Dig 2009;22(1):15-8

ABSTRACT - Background - The surgical treatment for perforated peptic ulcer is still a matter of discussion. The surgeons, for many years, made their options between acid-reducing procedures with some morbi-mortality and simpler procedures like closure of the perforation. But, in these cases, were faced with a high chance of ulcer relapse. Since the proved link between peptic ulcer and gastroduodenal infection caused by $\mathrm{H}$. pylori, a recommendation for a change in their attitudes going back to simpler procedures with eradication of the bacteria was done. Aim - To analyse ulcer recurrence in patients treated with the same surgical procedure but belonging to two different groups: positive and negative to H. pilori. Methods - A total of 144 patients were treated with simple closure of their perforated pre-pyloric, pyloric and duodenal ulcers. Thirty days after operation they were submitted to upper endoscopy and tested for the bacteria by urease and histopathological exams and divided into two groups according to the results of the tests: positive and negative. The positive ones were eradicated and, together with the negative group, were followed through six months interval endoscopies and detection tests looking for ulcer relapses and reinfection in the eradicated group. The positive group consisted of 25 patients, with two patients considered non eradicable according to the treatment protocol. They were followed for an average period of 38,21 months. Results - Relapse was detected in four patients $(17,39 \%)$, half of them $(8,69 \%)$ were reinfected. The negative group consisted of 26 patients, with a median follow-up of 38,28 months and eight (30,76\%) relapses were detected. There was no statistical significant difference due probably to the high dropout of patients. Conclusion - Simple suture with $\mathrm{H}$. pilori eradication is the gold standard for the positive group, leaving the question of acid-reducing procedures open for the negative ones.

HEADINGS - Peptic ulcer. Helicobacter pylori. Gastric ulcer. Perforated peptic ulcer. Duodenal ulcer.
\end{abstract}

\section{INTRODUCTION}

Although the treatment for peptic ulcer disease (PUD) has changed, the perforated ulcer - one of the most important complications -, did not present any important benefits. The incidence of perforated ulcer disease has remained virtually unchanged over the years ${ }^{11}$. Being the main cause of mortality on peptic ulcer disease ${ }^{4}$, the perforation affects patients in different age groups, young or elder $(20-40 \%)^{26}$, indicating the importance and severity of this disease.

The association between Helicobacter pylori and peptic disease is well established in the literature and in medical practice. Such connection has changed considerably the usual therapy ${ }^{10}$. The role of the bacteria on peptic ulcer

Trabalho realizado no Departamento de Cirurgia da Universidade Federal de Santa Maria e Serviço de Cirurgia Gastrointestinal do Hospital Universitário de Santa Maria, Santa Maria, RS, Brasil

Endereço para correspondência: Fernando O Souza, e-mail: fsouza@via-rs.net disease complications - like perforation -, is matter of discussion, concerning what would be the best surgical treatment for it: simple closure with omentopexy or acidreduction surgeries.

Inasmuch, peptic ulcer disease relapse rate after simple closure was too high, and so acid reduction surgery became the treatment of choice for perforated ulcers ${ }^{14}$. However, studies have shown that simple closure followed by $H$. pylori eradication diminished relapse rate ${ }^{1,3,7,12,15}$, $16,18,19,20,21,24,28$. Furthermore, shorter surgery time and easiness of the technique have encouraged surgeons to adopt this procedure in these situations.

The aim of this study is to analyze the relapse rate of peptic ulcer disease in patients with perforated ulcer, $\mathrm{H}$. pylori positives, submitted to simple suture of the lesion, omentopexy and eradication of the bacteria, and compare the data with a $\mathrm{H}$. pylori negative group submitted to the same surgical treatment. 


\section{METHODS}

All patients admitted in Emergency Service of University Hospital of Santa Maria's, Santa Maria, RS, Brasil, with acute abdominal pain due to perforated prepyloric, pyloric our duodenal peptic ulcer disease - confirmed by laparotomy -, from June 1997 to July 2007, were included in this study after a study's agreement term.

According to study's protocol, once the perforated gastric or duodenal ulcer was confirmed, all patients were submitted to its suture with omentopexy ${ }^{13}$, plus the usual procedures for peritonitis - cavity washing - biopsies or resection of gastric lesions.

On the 30th post-operative day, with absence of any antibiotics or proton pump inhibitor drugs for at least ten days, all patients were submitted to a upper endoscopy to evaluate the ulcerous lesion and the presence of $\mathrm{H}$. pylori infection. Two methods were used: random biopsies of the pyloric antrum and gastric body for histopathologic examination under Giemsa stain, and the urease test read within 24 hours. Also, a gastritis severity stratification was done in slight, mild or severe. Infection was considered positive results when it was confirmed by both exams.

According to these results, the patients were divided into two groups, based on the presence of H. pylori infection: the negative and the positive. The positive were treated with the association of amoxicillin, clarithromycin and proton pump inhibitor for seven days, aiming to eradicate the bacteria. Ninety days after the treatment was finished, the patients were submitted to a second upper endoscopy. The ones with a negative result were considered eradicated. The positive were submitted to the same treatment for 14 days, and the endoscopy was repeated 90 days after the treatment was concluded. Negative results were considered free of colonization; positive ones were considered not eradicable.

After the first upper endoscopy, all patients were required to attend to out-patient service every six months for sequential endoscopies, aiming to verify the status of the ulcer and the presence of $\mathrm{H}$. pylori.

All ulcers detected in the serial endoscopies were considered as relapses, exception made for the ones found in the first follow-up exam. In these cases, the lesions detected were seen as residual or under healing process.

All patients with positive results for $\mathrm{H}$. pylori after previous eradication were considered reinfected.

The statistical analysis was performed using Chi-square with Yates correction and Fisher's exact test to compare proportions, and Student $t$ test for numeric data. The significance value considered was 0,05 .

\section{RESULTS}

The initial amount of 144 patients had 14 nosocomial deceases $(9,7 \%), 44$ exclusion due to protocol errors, incorrect diagnosis (mostly perforated gastric adenocarcinomas), ulcers at locations other than pyloric or prepyloric, or non-attendance for the first upper endoscopy. After the first endoscopy, 35 patients were excluded due to out-patient follow-up dropout or discordance on H. pylori detection tests. The remaining 51 patients were included in the study.

These patients were divided into two groups, according to the presence or absence of $\mathrm{H}$. pylori infection. The group considered positive for the infection included 25 patients - 21 men and four women -, with an average age of 44,73 years. Two patients $(8 \%)$ were considered not eradicable according to the protocol criteria and were excluded from the final analysis. Both relapsed and one was submitted to truncal vagotomy plus Billroth I procedure, and the other one asymptomatic refused surgery. The remaining patients were eradicated from $\mathrm{H}$. pylori and followed-up for an average period of 38,21 months. They were submitted to 5,65 upper endoscopies per patient. Relapse was detected in four patients $(17,39 \%)$, half of them $(8,69 \%)$ presented with reinfection. The group considered negative for $\mathrm{H}$. pylori included 26 patients - 20 men and six women -, aging 49,84 years. The follow-up period was 38,38 months with an average of 5,03 endoscopies per patient. Relapse was detected on eight patients in this group (30,76\%).

The statistic comparison between the two groups concerning relapse did not show any difference for $P=0,05$ (Table 1).

\section{TABLE 1 - Patient groups}

\begin{tabular}{lccc}
\hline & HP + & HP - & P \\
\cline { 2 - 3 } & $\mathbf{( n = 2 3 )}$ & $\mathbf{( n = 2 6 )}$ & \\
\hline $\begin{array}{l}\text { Age(years) } \\
\text { Sex }\end{array}$ & $44,73+-14,89$ & $49,84+-14,97$ & $0.238^{*}$ \\
Female & 4 & & \\
Male & 19 & 6 & $0.890 \#$ \\
F o l l o w - u p & $38,21+-20,73$ & $38,38+-23,53$ & $0.979^{*}$ \\
(months) & $5,65+-2,91$ & $5,03+-2,90$ & $0.460^{*}$ \\
EGD & 4 & 8 & $0.451 \#$ \\
Ulcer recurrence & & & \\
\hline
\end{tabular}

*Student t test - \# Chi-square with Yates correction

\section{DISCUSSION}

The treatment for perforated ulcer is surgical in the majority of the cases, but the technique to be used is controversial. One option - simple closure - proved to result in high relapse rates $\left(36,6 \%\right.$ at 36 months $^{2}$ and $52 \%$ at 54 months ${ }^{5}$ ). Acid-reduction surgery is another option, but it carries on higher morbidity and mortality rates ${ }^{8,25}$. In 1984 , Marshall, et al. ${ }^{17}$ identified the bacteria Helicobacter pylori as the aetiological agent, introducing a new element for this discussion.

Studies have widely demonstrated that the eradication of $\mathrm{H}$. pylori diminishes relapse rates of non-complicated cases $^{10}$. But, the effect of $\mathrm{H}$. pylori eradication in complications of this disease, like perforation, is still a matter of research. From the year of 1995 on, several publications demonstrated that the simple closure of perforated ulcers, plus the eradication of $\mathrm{H}$. pylori, diminishes relapse rates significantly, inducing this strategy as treatment for this complication $1,3,7,12,15,16,18,19,20,21,24,28$. Historically, Sebastian, et al. ${ }^{24}$ were the first to suggest association between $\mathrm{H}$. pylori 
infection and peptic ulcer disease's relapse.

The mortality $(9,7 \%)$ in this study is corroborated by the literature. Sweeney, et al. ${ }^{27}$ reported mortality rates of $3-18 \%$, considering age, perforation time and comorbidities.

This study had a substantial dropout rate from the initial patient number $(51 \%)$. $\mathrm{Ng}$, et al. ${ }^{20}$ had a dropout rate of $48 \%$. The low adherence to this study can be justified by the following reasons: the hospital is difficult in access to other cities; the population related to it is mostly of low social level; and most patients were asymptomatic during the follow-up period.

Incidence of H. pylori infection on patients with perforation varies greatly amongst the various studies found in the literature. There are several different methods used for detecting the bacteria on each study, and different criteria used by each researcher to confirm the infection. The infection rate was of $49 \%$, using urease test and histopathologic analysis with positivity required on both. Kumar, et al. ${ }^{16}$ and $\mathrm{Chu}$, et al. ${ }^{6}$ used the same positivity criteria on their study (56\% and 47,2\% infection rate, respectively). Tran and Quandalle ${ }^{28}$ used three diagnostic tests: urease, histopathologic and serologic, requiring positivity in only one (96\% infection rate). Gisbert, et al. ${ }^{12}$ revised the literature on this subject, finding an average incidence of $68 \%$.

The exclusion criteria for this study removed patients with gastric ulcers other than pyloric or prepyloric. Rodriguez-Sanjuan, et al. ${ }^{21}$ also removed those patients, as they presented with a higher rate of ulcer re-perforation. These authors also contraindicate closure of gastric ulcers of locations other than those, for the relapse rate is too high.

Concerning the suspension time for the PPI drugs before the first endoscopy, Bose, et al. ${ }^{3}$ and $\mathrm{Ng}$, et al. ${ }^{20}$ suspended the drug 30 days before the $\mathrm{H}$. pylori detection tests were performed. This study suspended the drug at least 10 days before the tests. Since the incidence of $\mathrm{H}$. pylori infection is similar to the one found in the literature, it's possible to assume that difference did not interfered on the results here presented.

The eradication rate $(92 \%)$ is also similar to the ones found in the literature. Tran, et al. ${ }^{28}$ reported $95 \%$ and Metzger, et al. ${ }^{19} 96 \%$. An important detail that has been neglected by these authors is the reinfection rate. This study revealed a reinfection of $8,69 \%$ over an average follow-up period of three years, similar to the one found by Schutze, et al. ${ }^{23}$.
Concerning the main goal of this study, the detection relapse on patients without infection or eradicated from $\mathrm{H}$. pylori, there are some important matters to consider: this relapse rate for patients initially eradicated was of $17,39 \%$, whilst half of them $(8,69 \%)$ were reinfected patients, eligible for another eradication attempt. The relapse rate for patients that remained $\mathrm{H}$. pylori negative during follow-up was of $30 \%$. Bose, et al. ${ }^{3}$, with an average follow-up time of 18 months, accounted a relapse rate of $18,6 \%$ for the eradicated patients. $\mathrm{Ng}$, et al. ${ }^{20}$ reported a $38 \%$ relapse rate for the patients treated with an omeprazole monotherapy against a $4,8 \%$ rate for eradicated patients with a 12 months follow-up period. Rodriguez-Sanjuan, et al. ${ }^{21}$ related a $6,1 \%$ relapse rate for eradicated patients, with a 22 months follow-up period. This author, however, performed upper endoscopies on patients according to surgeon's criterion.

Laparotomic or laparoscopic suture of the ulcer, followed by omentopexy, should be the treatment of choice for perforated duodenal, pyloric or prepyloric ulcer, when associated with $\mathrm{H}$. pylori infection. The low mortality and relapse rates of this technique, plus its simplicity to be performed, justify its election. However, there is another significant group of patients: chronic users of non-steroidal anti-inflammatory drugs (NSAIDs), usually above 60 years old and $\mathrm{H}$. pylori-negative, which do not deserve eradication treatment.

For this last group of patients, on the impossibility of discontinuing the anti-inflammatory drugs, the associated use of PPIs did not reduce the risks of ulcer bleeding and perforation satisfactorily. Rostom, et al. ${ }^{22}$, over wide review, concluded that any PPI drug was effective in reducing the incidence of peptic ulcer disease on chronic NSAID users; however, only misoprostol reduced the risk of complications like bleeding and perforation.

\section{CONCLUSION}

During a perforated ulcer surgical handling, random specimens of the gastric antrum and body should be collected for rapid urease test. If it is positive for $\mathrm{H}$. pylori, the preferable procedure is perforation suture with omentopexy for duodenal ulcers, and ulcerectomy with closure for gastric ulcers. If the test is negative, an acid-reduction surgery is recommended. 
Souza FO, Dalcin SR, Dalcin RP, Abaid CA, Almeida PM, Adaime SB, Londero TM, Gai LV. Estudo comparativo quanto à recidiva ulcerosa do tratamento cirúrgico de úlcera péptica perfurada entre pacientes H. Pylori positivos, após erradicação, e negativos ABCD Arq Bras Cir Dig 2009;22(1):15-8

RESUMO - Racional - O tratamento cirúrgico da úlcera péptica perfurada é assunto discutível. Os cirurgiões, por muitos anos, fizeram suas opções entre procedimentos de redução ácida, somente fechamento da perfuração - porém com maior chance de recidiva ulcerosa. Desde a comprovada vinculação da úlcera péptica e suas complicações à infecção gastroduodenal causada pelo Helicobacter pylori, houve recomendação para mudança na atitude dos cirurgiões na volta à operação mais simples com erradicação da bactéria. Objetivo - Analisar a recidiva ulcerosa em pacientes com úlcera perfurada H. pylori positiva que foram submetidos à simples sutura da lesão e omentopexia com erradicação da bactéria e compará-la com H. pylori negativo submetido ao mesmo tratamento cirúrgico. Métodos - Cento e quatorze pacientes com úlceras pré-pilóricas, pilóricas e duodenais perfuradas foram atendidos com fechamento simples. Trinta dias após a operação submeteram-se à endoscopia digestiva alta com biópsias para testes da urease e histopatológicos. Foram divididos em dois grupos de acordo com o resultado dos testes: positivo e negativo.Os positivos foram erradicados e, junto com o grupo negativo, foram seguidos com endoscopias semestrais e testes de detecção para $\mathrm{H}$. pylori procurando por recidiva ulcerosa e reinfecção no grupo erradicado. Resultados - $\mathrm{O}$ grupo positivo foi formado por 25 pacientes, dos quais dois foram considerados não erradicáveis segundo os critérios do protocolo. Os demais foram seguidos por período médio de 38,21 meses e detectadas recidivas em quatro pacientes $(17,39 \%)$, metade deles $(8,69 \%)$ foram reinfectados. O grupo negativo foi formado por 26 pacientes, seguido por período médio de 38,28 meses e oito $(30,76 \%)$ apresentaram recidiva ulcerosa. Não foi evidenciada diferença estatisticamente significativa entre os grupos. Conclusão Em relação à recidiva ulcerosa, o fechamento simples seguido de erradicação da bactéria é o procedimento padrão para o grupo positivo; deixa-se em aberto a questão dos procedimentos ácido-redutores para o grupo negativo.

DESCRITORES - Úlcera péptica. Helicobacter pylori. Úlcera gástrica. Úlcera péptica perfurada. Úlcera duodenal.

\section{REFERENCES}

1. Bermejo F, Boixeda D, Gisbert JP, Defarges V, Martín de Argila C, Sanz JM, García Plaza A. Effects of Helicobacter pylori eradication on the recurrence of gastric ulcer during a 12-month follow up. Med Clin (Barc) 2000; 115(6):201-4

2. Boey J, Branicki FJ, Alagaratnam TT, Fok PJ, Choi S, Poon A, Wong J. Proximal gastric vagotomy. The preferred operation for perforations in acute duodenal ulcer. Ann Surg 1988; 208(2):169-74.

3. Bose, AC; Kate, V; Anathakrishnan, N; Parija, SC. Helicobacter pylori eradication prevents recurrence after simple closure of perforated duodenal ulcer. Journal of Gastroenterol Hepatol 2007; 22:345-8.

4. Branicki FJ. Risk factors, Helicobacter pylori and a role for laparoscopic treatment of perforated peptic ulcer. J Gastroenterol Hepatol 1996; 11:93-96.

5. Christiansen J, Andersen OB, Bonnesen T, Baekgaard N. Perforated duodenal ulcer managed by simple closure versus closure and proximal gastric vagotomy. Br J Surg 1987; 74(4):286-7.

6. Chu KM, Kwok KF, Law SYK, Tuen HH, Tung PHM, Branicki FJ, Wong J.

7. Helicobacter pylori status and endoscopy follow up of patients having history of perforated duodenal ulcer. Gastrointestinal Endoscopy 1999; 50(1):58-62

8. Datsis AC, Rogdakis A, Kekelos S, Zografos K, Sarantopoulou A, Spilliotis J. Simple closure of chronic duodenal ulcer perforation in the era of Helicobacter pylori: an old procedure, today's solution. Hepatogastroenterology 2003; 50(53):1396-8.

9. Donahue PE. Parietal cell vagotomy versus vagotomy-antrectomy: ulcer surgery in the modern era. World J Surg 2000; 24:264-9.

10. Donovan AJ, Berne TV, Donovan JA. Perforated duodenal ulcer - an alternative therapeutic plan. Arch Surg 1998; 133:1167-71.

11. Ford AC; Delaney BC; Forman D; Moayyedi P. Eradication therapy for peptic ulcer disease in Helicobacter pylori positive patients. Cochrane Database Syst Rev 2006; 2:CD003840.

12. Gama-Rodrigues JJ, Del Grande JC, Martinez JC. Tratado de clínica cirúrgica do sistema digestório. Editora Atheneu, 2004.

13. Gisbert JP, Pajares JM. Helicobacter pylori infection and perforated peptic ulcer prevalence of the infection and role of antimicrobial treatment. Helicobacter 2003; 8(3):159-67.

14. Graham RR. The treatment of perforated duodenal ulcers. Surg Gynaecol Obstet 1937; 64:235.

15. Griffin GE, Organ CH Jr. The natural history of perforated duodenal ulcer treated by suture plication. Ann Surg 1976; 183:382-5.

16. 15 Kate,V.; Ananthakrishnan, N.; Badrinath, S. Effect of Helicobacter pylori eradicate on the ulcer relapse after simple closure of perforated duodenal ulcer: retrospective and prospective randomized controlled studies. Br J Surg 2001; 88(8):1054-8.
17. Kumar D, Sinha AN. Helicobacter pylori infection delays ulcer healing in patients operated on for perforated duodenal ulcer. Indian J Gastroenterol 2002; 21(1):19-22.

18. Marshall BJ, Warren JR. Unidentified curved bacilli in the stomach of patients with gastritis and peptic ulceration. Lancet 1984; 1(8390):1311-5.

19. McFarlane G. Effect of Helicobacter pylori eradication on the ulcer recurrence after simple closure of perforated duodenal ulcer: retrospective and prospective randomized controlled studies. Lancet 1999; 354(9172):30-3.

20. Metzger J, Styger S, Sieber C, von Flüe M, Vogelbach P, Harder F. Prevalence of Helicobacter pylori infection in peptic ulcer perforations. Swiss Med Wkly 2001; 131(7-8):99-103.

21. Ng EK, Lam YH, Sung JJ, Yung MY, To KF, Chan AC, Lee DW, Law BK, Lau JY, Ling TK, Lau WY, Chung SC. Eradication of Helicobacter pylori prevents relapse of ulcer after simple closure of duodenal ulcer perforation. Ann Surg 2000; 231: 153-8.

22. Rodrıguez-Sanjuan JC, Fernandez-Santiago R, Garcıa RA, Trugeda S, Seco I, Torre F, Naranjo A, Gomez-Fleitas M. Perforated peptic ulcer treated by simple closure and Helicobacter pylori eradication. World J Surg 2005; 29: 849-52.

23. Rostom A, Dube C, Wells G, Tugwell P, Welch V, Jolicoeur E, McGowan J. Prevention of NSAID-induced gastroduodenal ulcers. Cochrane Database Syst Rev 2002(4):CD002296.

24. Schutze K, Hentschel E, Dragosis B, Hirschi AM. Helicobacter pylori reinfection with identical organisms: transmission by the patient's spouses. Gut $1995 ; 36: 831-33$.

25. Sebastian M, Prem Chandran VP, Elashaal YIM, Sim AJ. Helicobacter pylori infection in perforated peptic ulcer disease. Br J Surg 1995; 82:360-2.

26. Stabile BE. Redefining the role of surgery for perforated duodenal ulcer in the Helicobacter pylori era. Ann Surg 2000; 231(2):159-160.

27. Svanes C. Trends in perforated peptic ulcer: incidence, etiology, treatment and prognosis. World J Surg 2000; 24:277-83.

28. Sweeney KJ, Faolain MO, Gannon D, Gorey TF, Kerin MJ. Surgical management of perforated peptic ulcer disease. Ir J Med Sci 2006; 175(2):50-4.

29. Tran TT, Quandalle P. Treatment of perforated gastroduodenal ulcer by simple suture followed by Helicobacter pylori eradication. Ann Chir 2002; 127(1):32-4.

Fonte de financiamento: não há Conflito de interesse: não há Recebido para publicação: 11/07/2008 Aceito para publicação: 13/10/2008 